HORTSCIENCE 25(10):1224-1226. 1990.

\title{
Limb Girdling Influences Rooting, Survival, Total Sugar, and Starch of Dormant Hardwood Peach Cuttings
}

\author{
D.R. Evert and D.A. Smittle ${ }^{2}$ \\ Department of Horticulture, University of Georgia Coastal Plain \\ Experiment Station, Tifton, GA 31793 \\ Additional index words. Prunus persica, propagation
}

\begin{abstract}
Nonterminal cuttings were taken just after leaf fall (November) from nongirdled shoots and from shoots girdled 7 weeks previously on 'Flordaking', 'Junegold', and 'Harvester' peach trees [Prunus persica (L.) Batsch.]. Cuttings from nongirdled shoots rooted $(85 \%)$ and survived $(72 \%)$ better than did cuttings from girdled shoots on the same trees (64\% rooting, $49 \%$ survival). Total sugar averaged across cultivars was $68 \mathrm{mg} \cdot \mathrm{g}^{-1} \mathrm{dry}$ weight in cuttings from nongirdled shoots and $82 \mathrm{mg} \cdot \mathrm{g}^{-1} \mathrm{dry}$ weight in cuttings from girdled shoots. Starch averaged $26 \mathrm{mg} \cdot \mathrm{g}^{-1} \mathrm{dry}$ weight and was independent of shoot girdling. 'Flordaking' had the lowest starch concentration and the highest" percentage of cuttings that rooted and survived. Rooting and survival percentages differed by as much as $\mathbf{9 0 \%}$ among trees within each cultivar.
\end{abstract}

Several high-density systems for producing peaches require self-rooted trees (Couvillon et al., 1986; Erez and Yablowitz, 1981). Propagation of peaches from hardwood cuttings could provide low-cost plants, but poor rooting and survival of cuttings have been a problem (Bartolini et al., 1979; Yu and Robitaille, 1979). Girdling shoots before their removal from stock plants often improves rooting. Harmann and Kester (1975) wrote, "Girdling or otherwise constricting the stem, blocks the downward translocation of carbohydrates, hormones, and other possible root-promoting factors and can result in an increase in root initiation."

The time of year when hardwood peach cuttings are taken and set in the field affects cutting survival the following spring (Bartolini et al., 1979; Issell and Chalmers, 1979; Nam and Kim, 1985). In their reports, the best time to take cuttings varied from about leaf fall in November to late January. Differences in survival across dates maybe because of physiological changes in the trees and the cuttings with time, or may be influ-

Received for publication 6 Nov. 1989. The cost of publishing 'this paper was defrayed in part by the payment of page charges. Under postal regulations, this paper therefore must be hereby marked advertisement solely to indicate this fact. 'Associate Professor.

${ }^{2}$ Professor. enced by air and soil temperatures during the winter. A propagating medium at $25 \mathrm{C}$ gave poorer rooting of peach cuttings than 20C (Erez and Yablowitz, 1981). Cuttings taken just after leaf fall (November) gave the best survival in our preliminary studies,

The purpose of this study was to determine if shoot girdling before leaf fall would increase nonstructural carbohydrate levels, rooting, and survival of nonterminal cuttings taken just after leaf fall. Three cultivars were included to determine if the influence of girdling varied with cultivar.

Eleven trees of each of 'Flordaking', 'Junegold', and 'Harvester' peaches were selected 2 Oct. 1987, based on uniformity of growth and appearance. Trees of 'Flordaking' and 'Junegold' were on Nemaguard rootstock, and 'Harvester' was on Lovell rootstock. All trees were the same age and were from the same orchard. Survival of cuttings from these cultivars differed in preliminary experiments. A ring of bark $5 \mathrm{~mm}$ wide was removed on 2 Oct. 1987 at the base of the 1987 growth on at least nine shoots per tree. Girdled and check shoots were collected 24 Nov. 1987, after leaf fall, and 10 nonterminal cuttings were prepared from each group of shoots on each tree. The terminal $5 \mathrm{~cm}$ of each shoot was discarded as was the $5 \mathrm{~cm}$ adjacent to the girdle. Cuttings 15 to $20 \mathrm{~cm}$ long were wounded 2 to $3 \mathrm{~cm}$ along opposite sides of the base of each cutting 
Table 1. Effects of cultivar and shoot girdling on rooting, survival, total sugar, starch, and total nonstructural carbohydrates (total sugar + starch) of dormant hardwood cuttings of peach. ${ }^{2, y}$

\begin{tabular}{|c|c|c|c|c|c|}
\hline Variable & $\begin{array}{c}\text { Rooted } \\
(\%)\end{array}$ & $\begin{array}{l}\text { Live } \\
(\%)\end{array}$ & $\begin{array}{c}\text { Total sugar } \\
\left(\mathrm{mg} \cdot \mathrm{g}^{-1}\right)\end{array}$ & $\begin{array}{l}\mathrm{Starch} \\
\left(\mathrm{mg} \cdot \mathrm{g}^{-1}\right)\end{array}$ & $\begin{array}{c}\text { Total } \\
\text { nonstructural } \\
\text { carbohydrates } \\
\left(\mathrm{mg} \cdot \mathrm{g}^{-1}\right)\end{array}$ \\
\hline \multicolumn{6}{|l|}{ Cultivar } \\
\hline Flordaking & $84.6 \mathrm{a}$ & $74.7 \mathrm{a}$ & $78 \mathrm{a}$ & $18 \mathrm{~b}$ & $95 \mathrm{a}$ \\
\hline Junegold & $79.5 \mathrm{a}$ & $61.0 \mathrm{ab}$ & $71 \mathrm{a}$ & $34 \mathrm{a}$ & $106 \mathrm{a}$ \\
\hline Harvester & $59.5 \mathrm{~b}$ & $45.8 \mathrm{~b}$ & $76 a$ & $26 \mathrm{ab}$ & $102 \mathrm{a}$ \\
\hline \multicolumn{6}{|l|}{ Girdled } \\
\hline No & $84.7 \mathrm{a}$ & $71.8 \mathrm{a}$ & $68 \mathrm{~b}$, & $28 \mathrm{a}$ & $95 \mathrm{~b}$ \\
\hline Yes & $64.3 \mathrm{~b}$ & $49.2 \mathrm{~b}$ & $82 \mathrm{a}$ & $25 \mathrm{a}$ & $107 \mathrm{a}$ \\
\hline Interactions & NS & NS & NS & NS & NS \\
\hline
\end{tabular}

${ }^{2}$ All concentrations are on a dry weight basis.

'Mean separations within column by Tukey's test, $P \leq 0.05$; NS denotes not significant at $P \leq 0.10$.

Cultivar means contain 22 observations, and girdled means contain 33 observations.

(Couvillon et al., 1.986). After wounding, the base of each cutting was dipped for $5 \mathrm{sec}$ into $1000 \mathrm{mg} \mathrm{IBA} / \mathrm{liter}$ in $50 \%$ ethanol and allowed to dry (Hartmann and Kester, 1975).

The apical $1 \mathrm{~cm}$ of each cutting from girdled shoots was removed and pooled by tree. A similar sample was collected from the control cuttings. The pooled samples were dried at $90 \mathrm{C}$ to constant weight and then ground to pass through a 40 mesh screen. The samples were analyzed for total sugar and starch using the procedure of Dubois et al. (1956) as modified by Sistrunk (1965).

The cuttings were immersed in a fungicidal solution that contained Fosetyl-Al (Aliette $80 \mathrm{WP}$ at $1 \mathrm{~g} \cdot$ liter $\left.^{-1}\right)$ and 4-(1methylethyl)-2,6-dinifro- $N$ - $N$ - dipropylbenzenamine (iprodione)(Rovral 50WP at 1 $\mathrm{g} \cdot$ liter $^{-1}$ ) and then allowed to surface dry. Cuttings were set $<8 \mathrm{hr}$ after shoot collection in an area $1 \times 2 \mathrm{~m}$ of Tifton loamy sand (fine-loamy, Siliceous, Thermic Plinthic Paleudult) that had been fumigated with methyl bromide on 11 Nov. 1987 at a rate of $54 \mathrm{~g} \cdot \mathrm{m}^{-2}$. Rooting and survival were determined 28 Apr. 1988, $\approx 2$ months after bud break, when all living cuttings were growing rapidly. A cutting, whether alive or dead, was considered rooted if it had one or more roots at least $1 \mathrm{~cm}$ long. Live cuttings had several centimeters of new shoot growth and healthy green leaves.

The experimental design was a split plot with cultivars as main plots (the mainplot error term was the trees within cultivars) and with girdling as subplots. Data analyses used PROC GLM with means separation via Tukey's test (SAS Institute, Inc., 1985). Percentage data, which were based on 10 cuttings per sample, were transformed before analysis using the squareroot, arcsin transformation to stabilize the variance. Means were back-transformed for presentation.

A higher percentage of 'Flordaking' and 'Junegold' cuffings rooted than did 'Harvester' cuttings, and a higher percentage of 'Flordaking' cuttings survived than did 'Harvester' cuttings (Table 1). A higher percentage of 'Flordaking' cuttings root and survive than of most cultivars grown in this area (D.R.E., personal observation), and 'Flordaking' is one of the most vigorous cultivars grown in this area. Girdling decreased the percentage of cuttings that rooted (Table 1). The interaction of cultivar and girdling was not significant. The percentage of surviving cuttings varied among the trees within a cultivar $(P=0.007)$. Cutting survival ranged from $10 \%$ to $100 \%$ for individual trees of 'Flordaking' and 'Junegold' and from $0 \%$ to 90\% for 'Harvester'.

Cultivar had no effect on total sugar concentration and girdling increased total sugar concentration (Table 1). The increase in total sugar concentration in girdled shoots was independent of cultivar (Table 1), and the variation in total sugar concentrations among trees within a cultivar was not significant (data not shown).

'Flordaking', which is the most vigorous of the three cultivars, contained the least starch (Table 1). Girdling had no effect on starch concentration (Table 1). The interaction of cultivar and girdling was not significant for starch concentration, and the variation in starch concentration among trees within a cultivar was not significant (data not shown).

The total sugar concentration of cuttings from girdled shoots increased as expected (Hartmann and Kester, 1975; Stoltz and Hess, 1965), but the starch concentration was unchanged. However, Reuther and Reichardt (1963) found that the starch-to-sugar equilibrium in shoots responds quickly to changes in temperature. The difference between total nonstructural carbohydrate concentrations (sugar + starch) of 'Flordaking' and 'Junegold' was significant at $P=0.055$, but not at 0.05 , and the increase in nonstructural carbohydrates in girdled cuttings was significant at $P=0.003$ (Table 1). Variations in nonstructural carbohydrate concentrations among trees within a cultivar were not significant (data not shown).

Girdling usually increases rooting (Hartmann and Kester, 1983; Stoltz and Hess, 1965), so the decreased rooting and survival percentages for cuttings from girdled shoots were unexpected. The decreased rooting and survival occurred even though girdling increased the total sugar concentration in the cuttings as expected.

The variability in rooting and survival percentages among trees within a cultivar was also unexpected. Total sugar or starch concentrations did not vary among trees within a cultivar. Furthermore, the variability in rooting and survival percentages occurred among trees within a cultivar that were all the same age, in a single orchard, on the same seedling rootstock, and selected for uniformity. Variability in soil temperatures with cutting location in the propagation bed seems highly unlikely as an explanation of the variability in cutting survival between trees within a cultivar because the total area of the propagating bed was $2 \mathrm{~m}^{2}$. Soil temperatures averaged $16.3 \mathrm{C}$ at a depth of $10 \mathrm{~cm}$ for the 10 days beginning 24 Nov. 1987, the day the cuttings were taken. The maximum soil temperature at a depth of $10 \mathrm{~cm}$ remained below 23C from 24 Nov. 1987 to 2 Mar. 1988. These soil temperatures are favorable for rooting (Erez and Yablowitz, 1981).

Genetic variability among the seedling rootstock might explain the variability in rooting and survival among trees within a cultivar. Rootstock variability cannot explain why rooting and survival of cuttings from girdled shoots were lower than from nongirdled shoots on the same tree.

A possible source of the variability in rooting and survival of cuttings from trees within a cultivar and the decrease in rooting and survival caused by girdling could be fungi and bacteria in or on the shoots. Girdling could spread infections from shoot to shoot and infections could be systemic in the trees. Systemic infections would explain the lack of response to fungicides and to soil fumigants we found in other experiments (unpublished observations). Systemic infections also may explain the poor rooting and survival of peach cuttings reported by others (Bartolini et al., 1979; Yu and Robitaille, 1979). Alternatively, genetic variability among seedling rootstock could explain the tree-to-tree variability, and girdling could prevent the translocation of rooting inhibitors out of the shoots. Experiments are in progress to determine if the low survival rates are caused by infections or by genetic variability among seedling rootstock in combination with an accumulation of rooting inhibitors in girdled stems.

In summary, shoot girdling before leaf fall increased total sugar concentration but decreased rooting and survival percentages of nonterminal peach cuttings taken just after leaf fall. The rooting and survival percentages differed by as much as $90 \%$ among trees within a cultivar; thus, cutting survival depended more on the trees selected than on cultivar or shoot girdling.

\section{Literature Cited}

Bartolini, G., E. Bellini, and C. Messeri. 1979. Influence of sampling time on rooting of peach cultivar cuttings with different chilling requirements (in Danish). Estratto dalla Rivista Ortoflorofrutticoltura Italiana 63(5): 1-13.

Couvillon, G.A., F.A. Pokorny, and G. Scalabrelli. 1986. Production of inexpensive peach trees from rooted cuttings. Acts Hort. 160:413420

Dubois, M., K.A. Gilles, J.K. Hamilton, P.A. Reners, and F. Smith. 1956. Colormetric method of determining sugars and related substances. 
Anal. Chem. 28:350-356

Erez, A. and Z. Yablowitz. 1981. Rooting of peach hardwood cuttings for the meadow orchard. Scientia Hort. 15:137-144.

Hartmann, H.T. and D.E. Kester. 1975. Plant propagation principles and practices. 3rd ed. Prentice-Hall, New Jersey.

Issell, L.G. and D..J. Chalmers. 1979. The growth of clingstone peach trees [(Prunus persica $\mathrm{L}$. Batsch)] propagated from hardwood cuttings in relation to time of propagation and planting. J. Hort. Sci. 54:33-38.

Nam, K.U. and C.C. Kim. 1985. Studies on the propagation of peach trees by cuttings (in Korean). J. Korean Soc. Hort. Sci. 26(4):342-349. [Hort. Abstr. 57:6864;1987.]

Reuther, G. and A. Reichardt. 1963. Temperature effects on the blossoming and metabolism of Vitis vinifera. Planta 59:391-410.

SAS Institute, Inc. 1985. SAS user's guide: Sta- tistics. 1985 ed. SAS Institute, Inc., Cary, N.C. Sistrunk, W.A. 1965. Influence of post-harvest storage of snap beans on chemical and physical changes during canning. Food Res. 30:240-247. Stoltz, L.P. and C.E. Hess. 1965. The effect of girdling upon root initiation: Carbohydrates and amino acids. Proc. Amer. Soc. Hort. Sci. 89:734-743.

Yu, K.S. and H.A. Robitaille. 1979. Peach tree propagation from cuttings. HortScience 14(3):443. (Abstr.) 